\title{
GENETIC DIVERGENCE IN POPULATIONS OF Caryocar brasiliense Camb. FROM THE PHYSICAL CHARACTERISTICS OF THE FRUITS ${ }^{1}$
}

Paulo Henrique Rodrigues dos Santos ${ }^{2 *}$, Samuel Cunha Oliveira Giordani ${ }^{2}$, Blenda Calazans Soares ${ }^{2}$,

Fernando Higino Lima e Silva ${ }^{3}$, Elizabethe Adriana Esteves ${ }^{4}$ and José Sebastião Cunha Fernandes ${ }^{2}$

${ }^{1}$ Received on 03.10.2017 accepted for publication on 02.04.2018.

${ }^{2}$ Universidade Federal dos Vales do Jequitinhonha e Mucuri, Programa de Pós-Graduação em Produção Vegetal, Diamantina, MG- Brasil. E-mail: <santosphr@gmail.com>,<samuelgiordani@gmail.com>,<blendacalazans@hotmail.com>and $<$ jscf1912@gmail.com>.

${ }^{3}$ Instituto Federal Goiano, Departamento de Agronomia, Rio Verde, GO- Brasil. E-mail: <fernandohiginolima@gmail.com>.

${ }^{4}$ Universidade Federal dos Vales do Jequitinhonha e Mucuri, Departamento de Nutrição, Diamantina, MG- Brasil. E-mail: <eaesteves@yahoo.com.br>.

*Corresponding author.

ABSTRACT - The study of the genetic and phenotypic variability of the populations of Caryocar brasiliense Camb. assists in strategies for conservation and breeding of the specie. The objective of this work was to characterize the genetic diversity through the physical characteristics of pequi fruits of two populations through uni and multivariate analysis, as well as the implications in their domestication and breeding. Fruits were harvested from 20 mother trees (ten fruits per mother tree) from two populations in the state of Minas Gerais (Curvelo and São Gonçalo do Rio Preto Municipalities) during the years 2010, 2011 and 2012. The data were submitted to analysis of variance using a hierarchical classification model. An analysis of clusters and main components was used for studying the divergences. The effects of the populations were not significant for all the characters analyzed in isolation. The gathering of pequi mother trees shown by multivariate analysis did not correspond to the grouping established by the populations. Selection for breeding and/or preservation purposes should concentrate efforts on fewer populations with larger numbers of mother trees per population. Selection of mother trees with higher fruits and thicker pulp fruits among them, even by visual evaluations only, is recommend in sampling mother trees for breeding purposes.

Keywords: Pequizeiro; Genetic variability; Single and multivariate analyzes.

\section{DIVERGÊNCIA GENÉTICA EM POPULAÇÕES DE Caryocar brasiliense Camb. A PARTIR DE CARACTERÍSTICAS FÍSICAS DOS FRUTOS}

\begin{abstract}
RESUMO - O estudo da variabilidade genética e fenotípica das populações de Caryocar brasiliense Camb. auxilia nas estratégias para conservação e melhoramento da espécie. O objetivo deste trabalho foi caracterizar a diversidade genética por meio de características físicas de frutos de pequi de duas populações, mediante análises uni e multivariadas, bem como as implicações na sua domesticação e melhoramento. Foram colhidos frutos de 20 matrizes (dez frutos por matriz) oriundas de duas populações no estado de Minas Gerais (Municípios de Curvelo e São Gonçalo do Rio Preto) durante os anos de 2010, 2011 e 2012. Os dados foram submetidos à análise de variância utilizando-se um modelo de classificação hierárquica. Para o estudo das divergências utilizou-se a análise de agrupamentos e componentes principais. Os efeitos das populações foram não significativos para todos os caracteres analisados isoladamente. O agrupamento de matrizes de pequi, não corresponde ao agrupamento estabelecido pelas populações. Projetos para seleção e, ou preservação da espécie deverão concentrar esforços na obtenção de menos populações com maior número de indivíduos por população. Para a implementação de um teste de progênies para fins de melhoramento justifica-se a seleção de matrizes com os maiores frutos e, dentre estas, aquelas cujos frutos têm polpa mais espessa, mesmo que tais avaliações sejam apenas visuais.
\end{abstract}

Palavras-Chave: Pequizeiro; Variabilidade genética; Análises uni e multivariadas. 


\section{INTRODUCTION}

Savannas cover $20 \%$ of the earth's surface and account for approximately $30 \%$ of global primary net production. Among the savanna formations of the world, the Cerrado stands out as one of the centers of great biodiversity, with diverse flora and is rich in endemic species (Lehmann et al., 2014). The fruit species native to this biome have great acceptance in the consumer market, since their fruits have remarkable and peculiar flavors with high levels of vitamins, proteins and minerals (Silva et al., 2015; Soares et al., 2017). Among the species, the pequizeiro (Caryocar brasiliense Camb.), family Caryocaraceae, deserves special attention because it presents high occurrence in this biome (Oliveira et al., 2008; Ferreira et al., 2015), where it is considered a symbol of this typical Brazilian environment by local populations. Its fruit has a peculiar smell and flavor, and is very much appreciated by the populations in the regions of its occurrence.

The effect of populations and mother trees on variations in characteristics such as fruit size and pulp thickness is popularly known by people living with the species. In this way, researchers who are attentive to the observations of these communities perceive their preferences to certain mother trees whose fruits bear some qualities mainly related to the thickness and the flavor of the pulp (Soares et al., 2017).

With a closer look, it is possible to observe that these effects are extensive to fruit weight, putâmen, number of putâmens per fruit, and pulp weight, among others. Indeed, when the variations observed in these characteristics between mother trees are analyzed individually through univariate analyzes, they can be of great magnitude. On the other hand, from these analyzes it is observed that the effects of populations are not significant for the majority of populations (Oliveira et al., 2009; Silva et al., 2012; Soares et al., 2017). In this sense, the use of multivariate techniques is necessary to confirm these observations. These techniques allow the grouping of genotypes according to the similarities of the observed values for the different characters evaluated. When such genotypes come from different populations, it is possible to evaluate if the groups coincide with the populations, and consequently to infer about the distribution of the genetic variability between and within these populations.

Multivariate analysis techniques are widely-used tools in structural analyzes of forests in phytosociological studies, however, some researchers have been applying these techniques for evaluating plant biomass based on the physical and chemical characteristics of pequi fruits (Oliveira et al., 2009; Cordeiro et al., 2013).

Thus, the study of the genetic and phenotypic variability of the species' populations, could contribute to define strategies of conservation and use, such as the use of mother trees for the fruit production systems and use in breeding programs.

Considering the importance of the specie, this work aimed to characterize its genetic diversity through the physical characteristics of Caryocar brasiliense fruits of two populations via uni and multivariate analyzes and their implications in their domestication and breeding.

\section{MATERIALAND METHODS}

Fruits were collected from two sources in the state of Minas Gerais: one in the municipality of Curvelo (Experimental Farm of the Moura-UFVJM), and the other in the municipality of São Gonçalo do Rio Preto (State Park of Rio Preto - IEF).

The municipality of Curvelo is located in the central region of the state $\left(18^{\circ} 45^{\prime} 23^{\prime}\right.$ ' $\mathrm{S}$ and $\left.44^{\circ} 25^{\prime} 51^{\prime \prime} \mathrm{W}\right)$, with an average annual temperature of $28^{\circ} \mathrm{C}$, average precipitation of $1126 \mathrm{~mm}$ and altitude of $633 \mathrm{~m}$. The municipality of São Gonçalo do Rio Preto is located in the region of the Jequitinhonha Valley ( $18^{\circ} 07^{\prime} 2.6^{\prime \prime}$ $\mathrm{S}$ and $43^{\circ} 20^{\prime} 51.7^{\prime}, \mathrm{W}$ ), with an average annual temperature of $19^{\circ} \mathrm{C}$, average precipitation of $1300 \mathrm{~mm}$ and altitude $742 \mathrm{~m}$. The predominant climate in Curvelo and São Gonçalo do Rio Preto according to the Koppen classification are Aw and $\mathrm{Cwb}$, respectively (Botezelli et al., 2000; IEF, 2004).

The two populations are natural and considered reproductively isolated since the approximate linear distance between their localities is $137 \mathrm{~km}$.

The fruits were collected in the months of December and January in 2010, 2011 and 2012, at the complete maturation stage, meaning when they were lying on the ground.

Fruits were harvested from 20 mother trees previously identified in the field with metal plates, nine in Curvelo and 11 in São Gonçalo do Rio Preto in each year in order to perform the physical evaluations. It is noteworthy

Revista Árvore. 2018;42(1):e420116

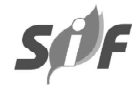


that 15 mother trees were sampled for each site and year. However, only 20 mother trees produced fruits in the three consecutive years.

After the collection the fruits were stored in duly identified plastic bags and conditioned in a refrigerator in the Integrated Laboratory of Multiuser Research of the Jequitinhonha and Mucuri Valleys (LIPEMVALE) in the years 2010 and 2011, and in a freezer in the Laboratory of Forestry and Plant Propagation (UFVJM) in the year 2012 until the moment of the analyzes.

The physical analyzes were carried out in the years of 2010 and 2011 in the Integrated Laboratory of Multiuser Research of the Jequitinhonha and Mucuri Valleys (LIPEMVALE) and in the Laboratory of Forestry and Plant Propagation (UFVJM) in the year 2012.

The following variables were evaluated: total fruit mass (MTF); mass of the external mesocarp (MME) per fruit; number of putâmens (drupes) (NP) per fruit; total mass of putâmens (MTP) per fruit; mean mass of putâmens (MMP) per fruit; total pulp mass (MPO) per fruit and mean pulp mass (MMPL) per fruit. For MPO and MMPL, the fruits were manually peeled and emptied with the help of a stainless steel knife. The masses were obtained with the aid of a semi-analytical digital scale.

The evaluation unit was composed of one fruit and each mother tree was represented by ten fruits taken at random, totaling 200 evaluations per variable in each year (10 fruits x 20 mother tree).

The model for the joint variance analysis involving the three years was $\mathrm{Y}_{\mathrm{ijk}}=\mathrm{m}+\mathrm{M}_{\mathrm{i}}+\mathrm{A}_{\mathrm{j}}+\mathrm{MA}_{\mathrm{ij}}+\mathrm{F}_{\mathrm{k} / \mathrm{j} \text { ' }}$, where $Y_{i j k}$ refers to the observation of fruit $k$ in year $\mathrm{j}$ of the mother tree $\mathrm{i} ; \mathrm{m}$ is the general average; $\mathrm{M}_{\mathrm{i}}$ refers to the effect of mother tree i, ignoring the effect of the population; $A_{j}$ refers to the effect of year $j ; \mathrm{MA}_{\mathrm{ij}}$ is the interaction between mother tree $\mathrm{i}$, ignoring the population effect, and year $\mathrm{j}$; and $\mathrm{F}_{\mathrm{k} / \mathrm{ij}}$ is the effect of fruit $\mathrm{k}$ within mother tree $\mathrm{i}$ and year $\mathrm{j}$.

The mean of the 10 fruits from each mother tree, was used in each year for the multivariate analysis. These mean values were used for cluster analysis using two procedures: a) Euclidian distance as a measure of dissimilarity and the Ward method for delimitation of groups; b) Principal Component Analysis, considering the first two extracted roots that presented the highest eigenvalues.

\section{RESULTS}

In the joint variance analysis, it is observed that the effects of mother trees within populations were highly significant $(\mathrm{P}<1 \%)$ for all variables, whereas those of populations were not significant. The variables MTF, MME, NP, MTP, MMP, MTLP and MMPL of the Curvelo population presented averages of 165.07; 130.09; $1.57 ; 34.98 ; 22.70 ; 15.75$ and 10.25 , respectively. For these same variables the means obtained in the Rio Preto population were $151.94 ; 118.16 ; 1.62 ; 33.78 ; 21.61$; 14.76; and 9.48, respectively (Table 1).

In the hierarchical dendrograms by the Ward method (Figure 1) constituted from the Euclidean distances and considering the physical characteristics of fruits of pequizeiros, basically two groups mostly constituted of different mother trees are observed with a greater degree of similarity in the years of 2010, 2011 and 2012, respectively. In 2010, seven mother trees were observed in a group, four (57\%) from Curvelo and three (43\%) from Rio Preto. On the other hand, there are 13 mother trees in the other group, with five (38\%) from Curvelo and eight (62\%) from Rio Preto. In the following year the two groups were composed of nine and 11 mother trees, being three (33\%) from Curvelo and six (67\%) from Rio Preto for the first year, and six (55\%) from Curvelo and five (45\%) from Rio Preto for the second year, respectively. In 2012, a group with six mother trees was observed: two (33\%) from Curvelo and four (67\%) from Rio Preto and another from 14, with the same number of mother trees from each population. The correlation coefficient of the dendrograms $(\mathrm{r}=$ $0.86,0.82$ and 0.85 for the years 2010, 2011 and 2012, respectively) showed a good fit between the graphic representation of the distances and their original matrix (Sokal and Rohlf, 1962), which immediately shows high reliability in the realization of inferences through the visual evaluation of Figure 1.

The effects of the populations were not significant for all characters analyzed alone (Table 1). There was also no trend of mother trees clustering according to their source populations in any of the evaluated years, either in a cluster analysis (Figure 1) or in plot dispersion (Figure 2). In these last two figures it is noteworthy that in addition to not having been a grouping consistent with the populations of origin in any year, the groupings that occurred in each year were different from each other. 
Table 1 - Significance $\mathrm{P}(\mathrm{F})$ for the model effects of an analysis of variance for physical traits ${ }^{1}$ of fruits collected from 20 pequi mother trees and average values by populations, in the years 2010, 2011 and 2012, coming from populations in nearby cities of Curvelo and S. G. do Rio Preto, MG state.

Tabela 1 - Níveis de significância $P(F)$ para os efeitos do modelo de uma análise de variância conjunta para variáveis físicas $^{1}$ de frutos de 20 matrizes de pequizeiro e valores médios por população, avaliados nos anos de 2010 , 2011 e 2012, provenientes dos municipios de Curvelo e S. G. do Rio Preto, MG.

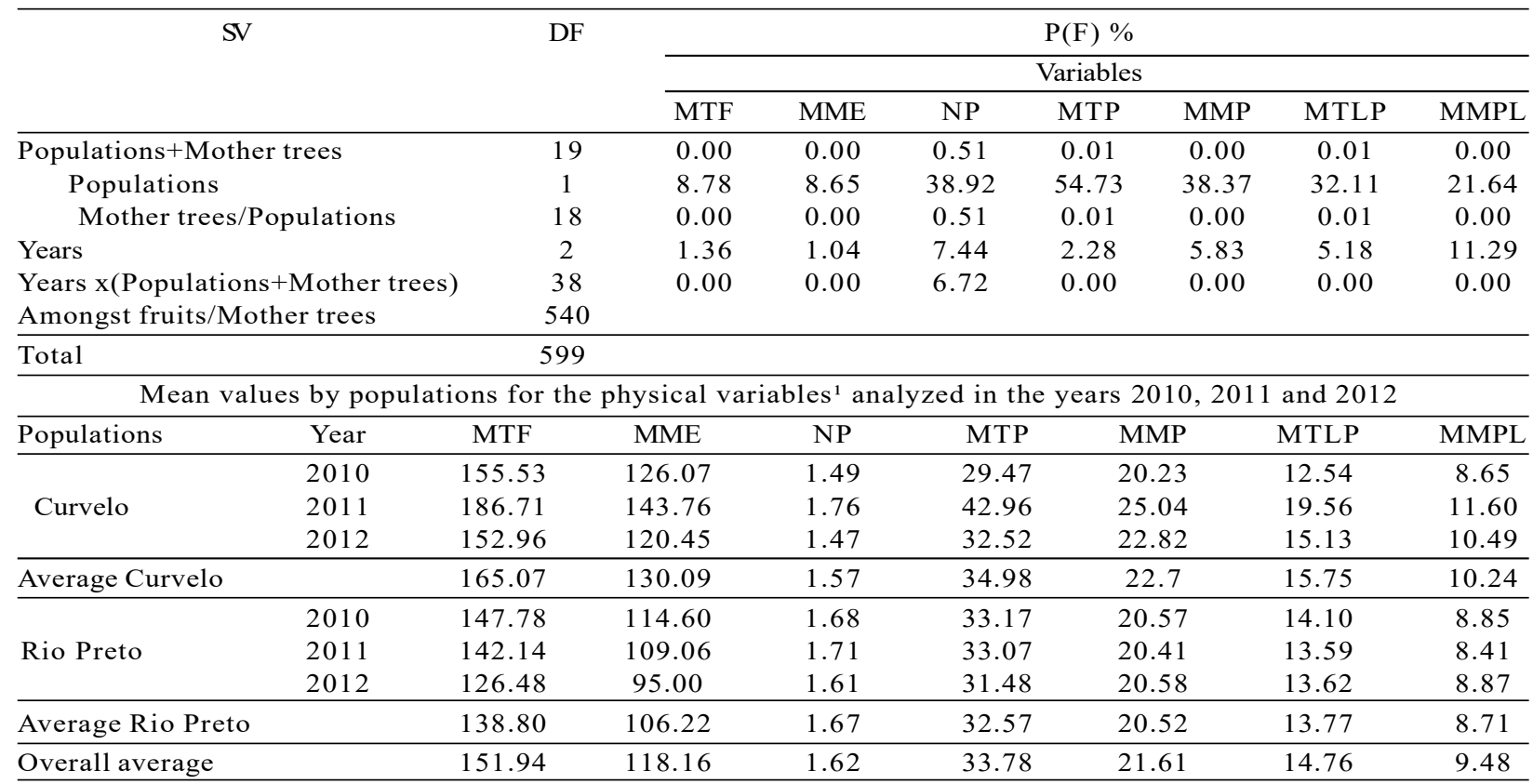

${ }^{1}$ MTF: total fruit mass; MME: external mesocarp mass; NP: number of putamens; MTP: total mass of putamens; MMP: mean mass of putamens; MTPL: total pulp mass; MMPL: mean pulp mass; all evaluated in grams (g).

Estimates of the relative contributions of each principal component variance, of cumulative relative contributions and of the correlation between the first principal component with each variable evaluated for the three evaluated years are shown in Table 2 . Considering that the proportion of total variation that is explained by the first two principal components ranged from 79.98 to $86.49 \%$ between years (Table 2 ), this proportion accounts for a considerable fraction of the available variation and meets the requirements, which is at least $80 \%$ for studies of divergence (Xavier et al., 1996; Cruz et al., 2011).

The dispersion plots (Figure 2) were produced from the first two principal components in the three years considered (Table 2).

Still regarding Table 2 , it is possible to observe the relative importance of the evaluated characteristics on the genetic diversity of pequizeiro mother trees, where the largest estimates of correlations with the

Revista Árvore. 2018;42(1):e420116 first principal component are observed for MTF and MME. This result is confirmed in Table 3, in which the characteristics that most contributed to the genetic divergence among mother trees were also for these two characteristics. This finding is not surprising, as when the sum of the variances of MTF and MME are computed in the original scale they correspond to 96.40 ; 92.06 and $93.75 \%$ of the total variances for all characteristics for the years 2010,2011, and 2012, respectively (data not shown).

\section{DISCUSSION}

The preponderance of genetic variation within populations in relation to variation between them is observed in several tree species for different phenotypic characteristics (Fernandes, 2008; Silva et al., 2012; Costa et al., 2016; Soares et al., 2017). These observations are also confirmed by studies carried out with the pequi tree in regions of northern Minas Gerais, where it was found that divergences among populations or between 

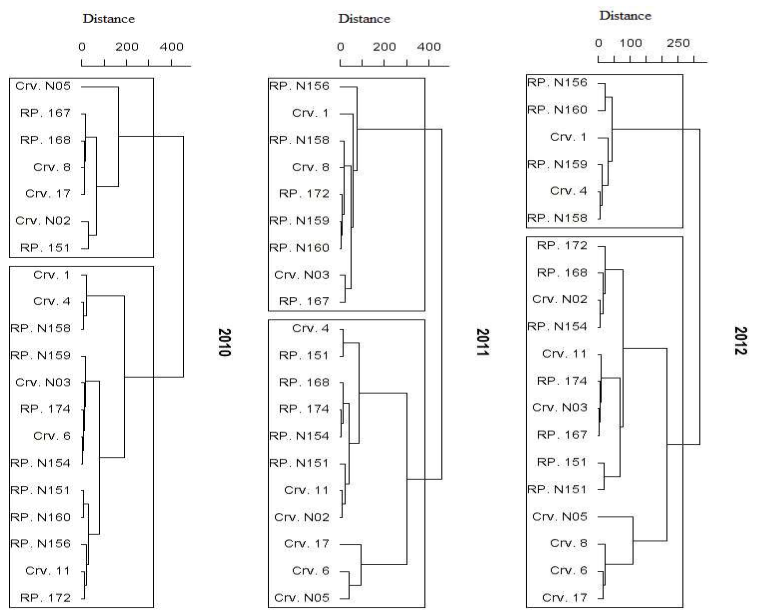

Figure 1 - Clustering defined by the Ward method from Euclidean distances, considering physical traits of fruits from 20 pequi mother trees in the years 2010,2011 and 2012, coming from populations in nearby cities of Curvelo and S. G. do Rio Preto, MG state. The value of the cophenetic correlation coefficient (r) is $0.86,0.82$ and 0.85 for the years 2010,2011 and 2012 , respectively.

Figura 1-Agrupamento definido pelo método Ward a partir de distâncias Euclidianas, considerando-se características físicas de frutos de 20 matrizes de pequizeiro nos anos de 2010, 2011 e 2012, provenientes dos municípios de Curvelo e $S$. $G$. do Rio Preto, MG. Ovalor do coeficiente de correlação cofenética (r) é de 0,86; 0,82 e 0,85 para os anos de 2010, 2011 e 2012, respectivamente.

groups of populations for this species are relatively low (Melo Júnior et al., 2004; Fernandes, 2008).

Vilela (1998) reported that in the case of the pequi tree, high gene flow and low divergence among populations may be related to its pollination system, which is mainly carried out by bats who fly great distances, and also by seed dispersal which is carried out by mammals and large birds. However, considering the wide distance $(137 \mathrm{~km})$ between the two populations in this study, the gene flow hypothesis between them can be ruled out. The hypothesis that they came from a single population and not a sufficiently long time is the most plausible explanation to justify the nonsignificance of its effects.

On the other hand, there are reports evidencing the existence of genetic differences between populations. Collevatti et al. (2001) analyzed 10 natural populations in a total of C. brasiliense 314 mother trees through microsatellites, finding a positive and significant correlation $(\mathrm{r}=0.518 ; \mathrm{P}=0.0396)$ between genetic distance and geographic distance. However, the authors sampled natural populations throughout the geographic distribution of the specie. In addition, because they are not subject to evolutionary forces and therefore to selection, the genetic polymorphism of molecular markers is much larger than that of phenotypic characters, with the latter being the object of the present study.

Table 2 - Ratio of the total (Var. \%) and total accumulated (Var. ac. \%) variance, expressed by principal components of seven physical traits in fruits of 20 pequi mother trees in the years 2010, 2011 and 2012, coming from populations in nearby cities of Curvelo and SG do Rio Preto, MG state.

Tabela 2 - Estimativa da proporção da variância total (Var. \%) e acumulada (Var. ac. \%), determinada pelos componentes principais de sete características fisicas em frutos de 20 matrizes de pequizeiro avaliadas nos anos de 2010, 2011 e 2012, provenientes dos municipios de Curvelo e S. G. do Rio Preto, ambos de MG.

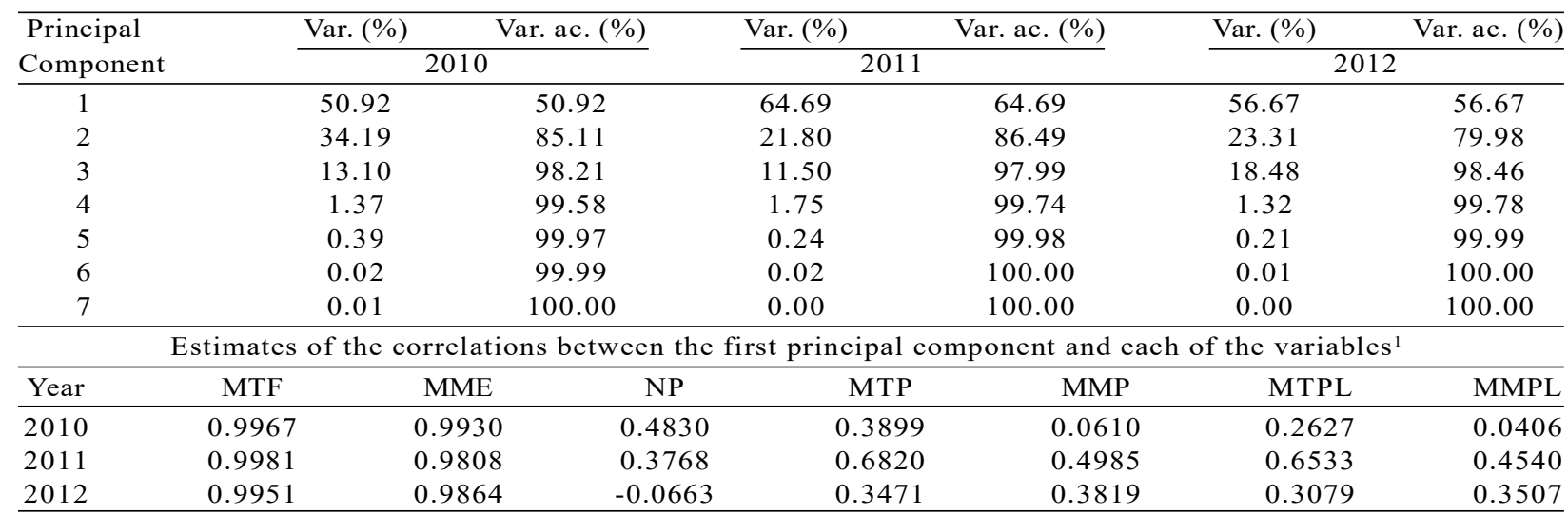

${ }^{1}$ Estimates of correlations using non-standardized data. 

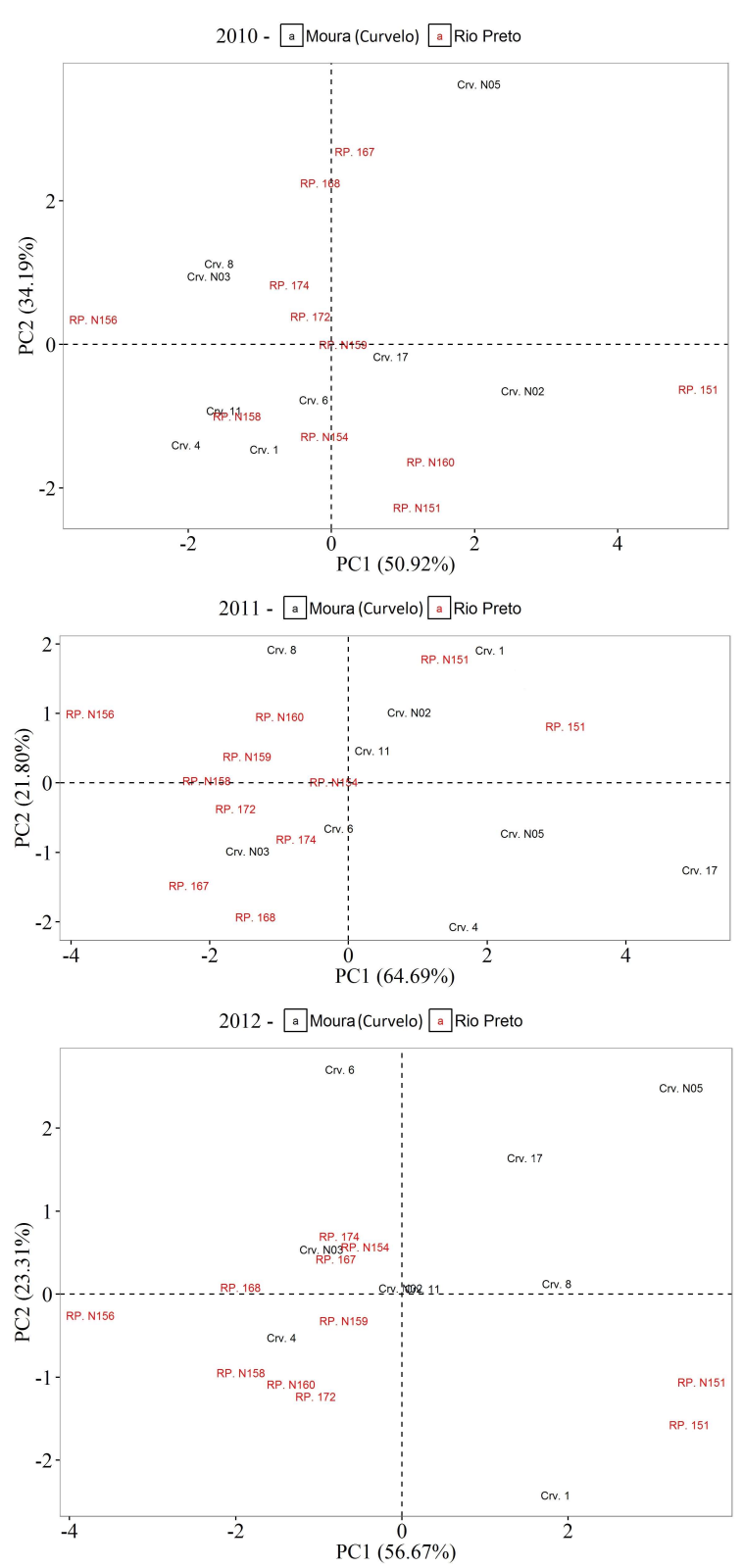

Figure 2- Scatter plots considering the first two main principal components, considering physical traits of fruits from 20 pequi mother trees in the years 2010, 2011 and 2012, coming from populations in nearby cities of Curvelo and S. G. do Rio Preto, MG state.

Figura 2 - Gráficos de dispersão considerando-se os dois primeiros componentes principais, estimados a partir de características físicas de frutos de pequizeiro nos anos de 2010, 2011 e 2012 provenientes dos municípios de Curvelo e $S$. G. do Rio Preto, $M G$.
Finally, the geographical diversity represented herein not only by the distance between the locations, but also for their edaphic and climatic characteristics, does not imply genetic diversity among populations, and in many cases there is no relationship between these (Cruz et al., 2012).

From the point of view of genetic improvement, the genetic variability that really matters is that referring to the phenotypic characters, especially those of economic importance. In this sense, and given the importance of the characteristics in question for consumers, a selection program for the species should focus efforts on obtaining fewer populations with a larger number of individuals per population. In turn, this also helps to preserve it, since the incorporation of Cerrado areas into Brazilian agriculture and the extent to which extractivist forms such as the pequizeiro have been exploited pose a major threat to the survival of this specie.

In a context involving several characteristics, the contribution of each is hardly the same for genetic divergence (Singh, 1981). On the other hand, the weight assigned to each characteristic for selection should not be the same in a breeding program (Cruz et al., 2011). The ideal situation would then be the one in which the most important characteristic was also the one that most contributed to the divergence.

Among the evaluated characteristics, the most important for the consumer is the total pulp weight (MTPL), which in considering the evaluated mother trees, presented low contribution to the genetic divergence of the populations in both environments and in three years of observation (Table 3 ). However, this does not imply that the genetic variability for such a characteristic is also low, since such contribution to divergence is relative to the other characteristics. Proof of this is the significance of the mother trees effect within populations for such characteristics (Table 1), as well as the $51 \%$ estimate found for the repeatability of this characteristic in these same mother trees and years (Soares et al., 2017).

It is also worth mentioning that the easiest evaluation among those considered is MTF and that the estimates of correlations between MTF and MTPL were $0.3358,0.6923$, and 0.3949 for the years 2010, 2011, and 2012, respectively (data not shown). This means that in selecting mother trees for the implantation of

Revista Árvore. 2018;42(1):e420116 
Table 3 - Relative contribution of traits to the dissimilarities on the Ward method clustering by Euclidean distances, considering physical traits of fruits of 20 pequi mother trees in the years 2010, 2011 and 2012, coming from populations in nearby cities of Curvelo and SG of Rio Preto, MG State.

Tabela 3 - Contribuição relativa de variáveis para as dissimilaridades usadas para o agrupamento pelo método Ward a partir de distâncias Euclidianas, considerando-se características físicas de frutos de 20 matrizes de pequizeiro nos anos de 2010, 2011 e 2012, provenientes dos municípios de Curvelo e S. G. do Rio Preto, ambos de MG.

\begin{tabular}{lccccc}
\hline Variable & S.j & Value (\%) & S.j & Value (\%) & S.j \\
\hline MTF & 579633.5 & 52.09 & 801841.0 & 55.60 & 403166.0 \\
MME & 493171.9 & 44.32 & 525870.0 & 36.46 & 337938.6 \\
MTP & 24808.4 & 2.23 & 71608.6 & 4.97 & 28382.0 \\
MMP & 7158.9 & 0.64 & 19366.5 & 1.34 & 12041.2 \\
MTPL & 5963.0 & 0.54 & 18038.6 & 1.25 & 7515.1 \\
MMPL & 2046.7 & 0.18 & 5495.6 & 0.38 & 1.52 \\
NP & 37.0 & 0.00 & 54.0 & 0.00 & 0.95 \\
\hline
\end{tabular}

MTF: total fruit mass; MME: external mesocarp mass; NP: number of putamens; MTP: total mass of putamens; MMP: mean mass of putamens; MTPL: total pulp mass; MMPL: mean pulp mass; all evaluated in grams $(\mathrm{g})$.

progeny tests, only evaluating the weight of its fruits is already a justifiable strategy.

\section{CONCLUSION}

The grouping of pequi mother trees originating from two populations geographically isolated from each other by considering characteristic evaluated in their fruits, does not correspond to the grouping established by the populations.

Projects for selection and preservation of the species should concentrate efforts to obtain fewer populations with higher numbers of individuals per population.

For implementing a progeny test for breeding purposes, selecting mother trees with the greatest fruits is justified, and among them those fruits which have thicker pulp, even if such evaluations are only visual.

\section{ACKNOWLEDGEMENTS}

CAPES, FAPEMIG and UFVJM for the technical and financial support and the Instituto Estadual de Florestas (IEF), for their support in collecting the fruits in the State Park of Rio Preto.

\section{REFERENCES}

Botezelli L, Davide AC, Malavasi MM.

Características dos frutos e sementes de quatro procedências de Dipteryx alata Vogel (Baru). Revista Cerne. 2000;6(1):9-18.

Collevatti RG, Grattapaglia D, Hay JD. Population genetic structure of the endangered tropical tree species Caryocar brasiliense, based on variability at microsatellite loci. Molecular Ecology. 2001;10:349-56.

Cordeiro MWS, Cavallieri ALF, Ferri PH, Naves MMV. Características físicas, composição químiconutricional e dos óleos essenciais da polpa de Caryocar brasiliense nativo do estado de mato grosso. Revista Brasileira de Fruticultura. 2013;35(4):1127-39.

Costa MF, Lopes ACA, Gomes RLF, Araújo ASF, Zucchi MI, Pinheiro JB et al. Caracterização e divergência genética de populações de Casearia grandiflora no cerrado Piauiense. Floresta e Ambiente. 2016;23(3):387-96.

Cruz CD, Ferreira FM, Pessoni LA. Biometria aplicada ao estudo da diversidade genética. Minas Gerais: Suprema Gráfica; 2011.

Cruz CD, Carneiro PCS, Regazzi, AJ. Modelos biométricos aplicados ao melhoramento genético. Viçosa, MG: UFV; 2012.

Fernandes RC. Diversidade e estrutura genética em populações naturais de pequizeiro (Caryocar brasiliense Camb.) no norte de Minas Gerais [dissertação]. Lavras: Universidade Federal de Lavras; 2008.

Ferreira GA, Naves RV, Chaves LJ, Veloso VRS, Souza ERB. Produção de frutos de populações naturais de pequizeiro no estado de Goiás. Revista Brasileira de Fruticultura. 2015;37(1):121-9. 
Instituto Estadual de Florestas, MG - IEF. Plano de Manejo do Parque Estadual do Rio Preto.

Encarte 3 - Análise da Unidade de Conservação. Belo Horizonte: 2004.

Lehmann CER, Anderson TM, Sankaran M, Higgins SI, Archibald S, Hoffmann WA et al. Savanna vegetation-fire-climate relationships differ among continents. Science. 2014;343:548-52.

Melo Junior AF, Carvalho D, Póvoa JSR, Bearzoli E. Estrutura genética de populações naturais de pequizeiro (Caryocar brasiliense Camb). Scientia Forestalis. 2004;66:56-65.

Oliveira MEB, Guerra NB, Barros LM, Alves RE. Aspectos agronômicos e de qualidade do pequi. Fortaleza: Embrapa Agroindústria Tropical; 2008.

Oliveira MEB, Guerra NB, Maia AHN, Alves RE, Xavier DS, Matos NMS. Caracterização física de frutos do pequizeiro nativos da Chapada do Araripe - CE. Revista Brasileira de Fruticultura. 2009;31(4):1196-201.

Silva FHL, Fernandes JSC, Esteves EA, Pinto NAVD, Santana RC, Santos PHR. Procedências, matrizes e diâmetro do tronco na expressão de variáveis químicas em frutos de pequizeiro. Revista Brasileira de Ciências Agrárias. 2015;10(1):134-9.
Silva FHL, Fernandes JSC, Esteves EA, Titon M, Santana RC. Populações, matrizes e idade da planta na expressão de variáveis físicas em frutos do pequizeiro. Revista Brasileira de Fruticultura. 2012;34(3):806-13.

Singh D. The relative importance of characters affecting genetic divergence. The Indian Journal of Genetics and Planta Breedings. 1981;41:237-345.

Soares BC, Santos PHR, Silva FHL, Esteves EA, Titon M, Fernandes JSC. Repeatability of physical and chemical characteristics in pequi fruits. Revista Brasileira de Fruticultura. 2017;39(2):1-12.

Sokal RR, Rohlf FJ. The comparison of dendrograms by objective methods. Taxon. 1962;11(2):33-40.

Vilela GF. Variações naturais de Caryocar brasiliense Camb. (Cariocaraceae): fenológicos, genéticas e de valores nutricionais de frutos [dissertação]. Lavras: Universidade Federal de Lavras; 1998.

Xavier A, Borges, RCG, Cruz CD, Cecon PR. Aplicação da análise multivariada da divergência genética no melhoramento de Eucaliptus spp. Revista Árvore. 1996;20(4):495-505. 